University at Buffalo School of Law

Digital Commons @ University at Buffalo School of Law

Journal Articles

Faculty Scholarship

4-30-2019

\title{
Legal Consciousness Reconsidered
}

Lynette J. Chua

National University of Singapore

David M. Engel

University at Buffalo School of Law

Follow this and additional works at: https://digitalcommons.law.buffalo.edu/journal_articles

Part of the Law and Society Commons, and the Legal Studies Commons

\section{Recommended Citation}

Lynette J. Chua \& David M. Engel, Legal Consciousness Reconsidered, 15 Ann. Rev. L. \& Soc. Sci. 335 (2019).

Available at: https://digitalcommons.law.buffalo.edu/journal_articles/966

Posted with permission from the Annual Review of Law and Social Science, Volume 15. (C2019 by Annual Reviews, http://www.annualreviews.org.

\section{C) ${ }_{\text {COPYRIGHT }}^{\text {N }}$}

This Article is brought to you for free and open access by the Faculty Scholarship at Digital Commons @ University at Buffalo School of Law. It has been accepted for inclusion in Journal Articles by an authorized administrator of Digital Commons @ University at Buffalo School of Law. For more information, please contact lawscholar@buffalo.edu. 


\title{
Legal Consciousness Reconsidered
}

\author{
Lynette J. Chua* and David M. Engel**
}

\begin{abstract}
Legal consciousness is a vibrant research field attracting growing numbers of scholars worldwide. Yet differing assumptions about aims and methods have generated vigorous debate, typically resulting from a failure to recognize that three different clusters of scholars - identified here as the Identity, Hegemony, and Mobilization schools - are pursuing different goals and deploying the concept of legal consciousness in different ways. Scholarship associated with these three schools demonstrates that legal consciousness is actually a flexible paradigm with multiple applications rather than a monolithic approach. Furthermore, a new generation of scholars has energized the field in recent years, focusing on marginalized peoples and non-Western settings. Through their findings, and as a result of broader trends across the social sciences, relational legal consciousness has taken on greater importance. Legal consciousness research should be imagined on a continuum ranging from individualistic conceptualizations of thought and action to interactive, co-constitutive approaches.
\end{abstract}

\section{INTRODUCTION}

For more than a century, sociolegal scholars have sought to explain when and how law becomes active in social life. Not content to analyze the claims brought by legal professionals in official forums, these researchers have looked beyond the courthouse and even the lawyer's office. They have found that law tends to insinuate itself into the cracks and crevices of daily routines, and its direct and indirect influence can be detected in the most mundane and seemingly nonlegal interactions of everyday life. A central finding of sociolegal research from its earliest days to the present has been the impossibility of separating the social or cultural from the legal, so strong is their bond.

\footnotetext{
* Faculty of Law, National University of Singapore; email: lynettechua@nus.edu.sg

** School of Law, State University of New York at Buffalo; email: dmengel@ buffalo.edu
} 
Given this long-standing fascination with the relationship between law and quotidian social practices, the question remains how the law-culture-society nexus should best be studied. What theories and methods are most suited to explore these interactive effects? There has been extraordinary diversity in our field on these matters. In some respects, the story is one of "restless searching" for new and better research paradigms (Munger 1998).

One of the most prominent paradigms today is that of legal consciousness, which emerged in the early 1980s and has since been adopted by growing numbers of researchers. This article traces the development of legal consciousness research over nearly four decades and suggests a promising direction that future scholars may follow. It starts with definitions and applications by sociolegal scholars whose differing objectives have led to three distinctive schools of research. It then examines a period of turbulence and self-reflection among legal consciousness scholars at the turn of the twenty-first century and a period of exuberant expansion in the years that followed. The remainder of the article identifies relational legal consciousness as an important trend for future sociolegal research.

\section{FOUNDATIONS}

\section{Defining Legal Consciousness}

Different scholars have adopted dissimilar approaches to research on legal consciousness and have proposed a plethora of definitions (see, e.g., Albiston 2006, Ewick \& Silbey 1998, McCann 1994, Merry 1990, Nielsen 2000). We begin by offering our own. In this article, legal consciousness refers to the ways in which people experience, understand, and act in relation to law. It comprises both cognition and behavior, both the ideologies and the practices of people as they navigate their way through situations in which law could play a role. Legal consciousness does not simply refer to legal awareness, nor is it meant to measure knowledge - or ignoranceof the law. Indeed, some legal consciousness research demonstrates the extent to which people do not invoke or think about the law at all—or perceive it to be irrelevant. Often enough legal consciousness research documents the absence as well as the presence of law in people's understanding of the social world and their place in it. Like the Cheshire Cat, law appears and disappears in the picture of everyday life drawn by legal consciousness researchers.

According to our definition, and consistent with most of the literature on the topic, three elements of subjectivity are of primary interest to legal consciousness scholars, regardless of 
their research methods or theoretical orientation: worldview, perception, and decision. None of these three elements is given; all emerge in distinctive ways from social interactions, and all are interconnected.

Worldview. Worldview refers to individuals' understanding of their society, their place in it, their positions relative to others, and, accordingly, the manner in which they should perform social interactions. Worldview manifests in individuals' constructions of self or identity, and it plays out in their relationships with other people, groups, and institutions, as well as the natural and spiritual worlds in which they live. It emerges from their prior experiences, and it influences how they perceive and respond to new experiences - and whether they should mobilize the law. Perception. Perception refers to individuals' interpretation of specific events. People may, for example, perceive a new event as normal, problematic, harmful, or wrong. For individuals who perceive an event as unexceptional, law may seem immaterial; for those who perceive the same event as violative of interests or rights, law may seem significant. With experience, of course, one's perceptions of events can change. For example, an encounter with an activist or lawyer may shift an individual's perception toward legal rights.

Decision. Decision refers to individuals' responses to events and typically reflects both their worldview and perception. Decisions may at times involve deliberate choices to use the law but at other times to leave it dormant. A decision and its outcome form a new experience that can reconstitute the individual's worldview and perceptions for the future.

The attention legal consciousness researchers began to give issues of worldview, perception, and decision in the 1980s reflected a broad shift in sociolegal scholarship toward the study of subjectivity in law, particularly among lay actors. What Seron \& Silbey (2004) have described as sociolegal scholarship's "cultural" turn was in fact part of a trend in contemporary social theory toward cognition and social construction (Albiston 2006). It is from these developments that legal consciousness research emerged, as well as from earlier sociolegal research on legal culture, legal pluralism, and dispute processing. Despite these commonalities in the evolution of legal consciousness research, however, there was no unanimity concerning theories or methods in the field. We turn next to the differing ways in which sociolegal scholars have framed their explorations of legal consciousness issues.

\section{Three Schools of Legal Consciousness Research}


As legal consciousness research gathered momentum in the mid-1980s and proliferated in the late twentieth century, it became apparent that researchers were approaching their work in divergent ways, leading to the emergence of three schools, which we call Identity, Hegemony, and Mobilization. Whether the scholars whose work we assign to these three schools would accept our classification remains to be seen. In fact, the lines are not always bright and clear. The work of some scholars draws on more than one school of thought, and research in all three schools tends to overlap and interact in synergistic ways. Yet the differences among the three schools are not trivial, and the failure to recognize their divergent aims and assumptions has generated a degree of confusion and even conflict — unnecessarily so, in our view, because the goals being pursued are simply not the same. In this section, we explain these differences and highlight how each school engages with the three constitutive elements of legal consciousness discussed above — worldview, perception, and decision making.

\section{Identity.}

The Identity school treats individual subjectivity in relation to law as the explanandum - the phenomenon demanding critical investigation and analysis. It emphasizes the fluidity and multiplicity of legal consciousness and identities and eschews fixed categories or typologies. ${ }^{1}$ Legal consciousness and identity emerge from and shape one another. Thus, for the Identity school, the place of law in people's lives is intimately connected to their sense of who they are, which is itself a product and producer of their worldview. Upon encountering new events, individuals may regard law as irrelevant if their identity seems consonant with those events. That being so, their perception makes the circumstances seem natural, and they are likely to decide there is nothing for the law to fix. If, however, events appear incongruent with their identity, individuals may perceive the circumstances as unfair and decide to take legal action. Such actions, of course, include not only the official use of legal institutions but also the verbal threat to claim one's rights, or the use of legal terms or concepts in everyday discourse, or even the influence of inarticulate thought processes that are shaped by legal norms.

A representative work of the Identity school by Engel \& Munger (2003) highlights the

\footnotetext{
${ }^{1}$ Some identities are externally imposed, whereas others are internally created self-conceptions. As Goffman (1963) on "spoiled identities" suggests, the two are inseparable and mutually constructed.
} 
mutually constitutive relationship between legal consciousness and identity in adults with disabilities. Told through life story narratives, legal consciousness for these men and women was very much a matter of identity construction rather than the instrumental deployment of rights. Their interviewees never brought legal claims and seldom consulted lawyers, even though virtually all of them felt they had been treated unfairly and their career prospects had been damaged by discrimination. Although they worried that legal claims could irreparably harm the identities to which they aspired, many of them also made it clear that law had become active in their lives indirectly or constitutively - by altering their identities. Law had changed their assumptions about who they were and where they belonged, and it had led them to imagine careers that would have been unthinkable to a previous generation before the enactment of disability rights legislation.

Because of its insights into the fluidity and multiplicity of identities and legal consciousness, the Identity school of legal consciousness research exposes the paradoxical impact of legal claiming on subordinated identities. To the marginalized, law may seem a double-edged sword; as they assert legal rights based on an identity protected by the law to win acceptance and inclusion, they find themselves constructing an identity that may actually be stigmatized and oppositional (ㅆinow 1990).$^{2}$ A brilliant example is Hartog's (1995) historical account of an eighteenth-century American woman named Abigail Bailey. Bailey's husband attacked her and raped their teenaged daughter. As a married woman subject to the eighteenth-century legal doctrine of coverture, Bailey's identity was covered by that of another-her brutal husband. Bailey's thoughts and actions owed a great deal to her religious self-conception, but the law did play a critical role. At the same time that law shaped her identity as a disempowered and often submissive woman, it also offered access to powerful avenues of resistance. In the end, when Bailey used the law to attain freedom for herself and her children, she overcame the restrictions imposed by the legal doctrine of coverture, but she also reinscribed her identity, not as a free and independent woman but as an obedient and subordinate subject. To abide by the legal definition of a good wife, Bailey had no choice but to seek a separation or else be deemed complicit in her husband's illegal acts.

\footnotetext{
${ }^{2}$ Although Minow (1990) does not focus explicitly on the topic of legal consciousness, she raises issues that have proved highly influential for scholars of the Identity school.
} 
Recent studies in the Identity school have proved consistent with these earlier works. Kirkland (2008) shows how the social identity of fat people paradoxically makes legal claims of discrimination both inviting and risky. Kirkland's interviewees did not consider legal action to combat unfair treatment on the job and instead worked hard at identity construction. Some of them conceptualized their mistreatment through the terminology of antidiscrimination law, adopting what Kirkland calls "rights discourse," but recognized that legal protections for fat people are weak. In any case, they preferred not to pursue any strategy that would characterize them as abnormal or "disabled." In Abrego's (2008) study of undocumented immigrant students following the enactment of California Assembly Bill 540, which exempted them from paying nonresident tuition for higher education, the interviewees viewed law as both oppressive and liberating. Immigration laws and their enforcement contributed to an identity that made the students seem alien and threatening. However, these same laws also offered protections and opportunities, such as access to higher education without a requirement that the students categorize themselves in stigmatizing terms. In this sense, the law strengthened their identities as educated professionals even as it marginalized them. ${ }^{3}$

Many other legal consciousness studies could be categorized in the Identity school as we have defined it. Furthermore, it is no exaggeration to say that virtually every study of legal consciousness has implications for identity, because law is invoked only by those who possess an identity that makes them perceive law to be relevant to their circumstances. Furthermore, every decision to invoke law has an impact on the identity of those who claim it. The mutually constitutive effects of law and identity are therefore relevant to the entire field of legal consciousness research, yet we shall see that other concerns become much more prominent for scholars whom we categorize in the remaining two schools.

\section{Hegemony.}

The Hegemony school views law as a pervasive and powerful instrument of state control that shapes the worldviews, perceptions, and decisions of individuals, even when it is not applied

\footnotetext{
${ }^{3}$ Although Abrego (2008) draws rather positive conclusions about the beneficial effects of one particular law, her research on the whole fits well within the Identity school. It demonstrates the mutually constitutive effects of law and identity formation, and it reminds us that law remains a highly variable factor in relation to identity.
} 
directly or instrumentally. For most proponents of the Hegemony school, the purpose of legal consciousness research is to reveal the workings and expose the far-reaching yet often invisible effects of law in the thoughts and actions of ordinary people. At the same time, many Hegemony scholars seek to reveal how some individuals resist law's powerful effects, albeit in ways that reinforce or leave intact law's superordinate power. Although subjectivity of the individual is important, it is not itself the explanandum but serves primarily to reveal the effects of legal power.

The pervasive and unquestioned nature of law's power appears prominently in the Hegemony school's most representative works. For the welfare recipients Sarat (1990, pp. 345-46) studied, law was "all over," a "shadowy presence" of "power and of compulsion." In terms of the three elements by which we have defined legal consciousness, law imposed a subordinated worldview for welfare recipients that dictated their bleak perceptions about life's most pressing needs and constrained decisions about personal and private aspects of their lives. Ewick \& Silbey's (1998, p. 247) survey subjects also viewed the law as a "durable and powerful" presence in everyday life, but not because it invariably required obedience to its commands. Rather, law achieved hegemony by being constantly produced and reproduced in the "common place" thoughts and actions of ordinary people. To put it in the terminology we have proposed, Ewick \& Silbey suggest that these interviewees perceived events and made decisions in response to them in different ways. Some perceived the law as "majestic," whereas others viewed it as "a game" or attempted to go "against" it. Their decisions varied according to these differing perceptions, and their worldviews evolved as a result of their life experiences. Nonetheless, law continuously penetrated and pervaded their lives. No matter how they responded, they could not help but sustain law's hegemonic power over social life and reinforce its authority and control. In a prior

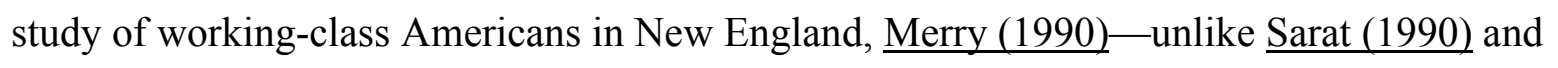
Ewick \& Silbey (1998) - focused on litigation rather than problems that did not necessarily come to the attention of legal professionals, but she reached similar conclusions. Merry, too, highlighted the extent to which law exerted control over the perceptions of issues and the decisions people made in response to them. Her interviewees came to court believing they were entitled to its protection, but court officials often reinterpreted their neighborhood and family problems as "garbage cases" and offered nonlegal solutions, denying them the protection they expected the legal system to provide (180; see also Yngvesson 1993). As a result, their 
experiences with the courts altered their worldviews and perceptions of themselves and their problems.

According to the Hegemony school, even when individuals engage in counter-hegemonic acts of resistance and go "against the law" (Ewick \& Silbey 1998), they cannot overcome law's inescapable, constitutive reach into social life. A few welfare recipients in Sarat's (1990) study did resist the law by seeking legal assistance; however, the Hegemony school would argue that they failed to displace law's hegemonic status. Such acts of resistance bring brief reprieves and small victories but ultimately sustain law's power (Silbey 2005). This is because, consistent with the concepts of "tactical resistance" (Sarat 1990 and Ewick \& Silbey 1998, citing de Certeau $\underline{1984}$ ) and disciplinary power (Ewick \& Silbey 1998, citing Foucault 1980), resistance operates between law's cracks and thus within its logic and understandings, rather than outside its framework. Even as they attempt to resist, these individuals "ultimately reproduce state law's legitimacy and power" (Wilson 2011, p. 481).

Although Ewick \& Silbey's intellectual motivation was to expose the hegemonic power of law (see Silbey 2005), many legal consciousness studies in the Hegemony school have placed primary emphasis on elucidating tactics of resistance (see, e.g., Gilliom 2001). Kostiner (2003) explores the counter-hegemonic possibilities of resistance against law among social justice activists in the San Francisco Bay Area and concludes that social change may be possible despite law's hegemony if activists adopt primarily nonlegal strategies. Fritsvold (2009) takes the analysis of resistance even further. To the radical environmentalists in his study, law is a hegemonic power to be challenged in toto for protecting an illegitimate social order. Carrying out civil disobedience and deliberately breaking the law, they do more than mount covert resistance. Because these activists go beyond the form of legal consciousness Ewick \& Silbey describe as "against the law," Fritsvold offers "under the law" as a fourth addition to their three schemas.

\section{Mobilization.}

Members of what we call the Mobilization school study legal consciousness to understand law's potential for transforming society, particularly by deploying rights that are intended to achieve justice or protect disadvantaged populations. Some Mobilization scholars study the legal consciousness of individuals or groups to gauge the extent of social change that has occurred, whereas others study it to explain the dynamic cognitive processes that lead people to bring 
about change. In either case, studying legal consciousness helps Mobilization scholars to view social change through the lens of human agency, thereby augmenting the more typical research on social change that tends to adopt an aggregate and distanced perspective.

Among Mobilization scholars who study individual legal consciousness to measure the extent of law's impact on social change, some highlight the role of local norms and practices in constraining people's invocation of law. To put the matter in the definitional terms we have proposed, these researchers show how local norms and practices limit law's potential influence on social change by shaping the worldviews of individuals such that they do not perceive law as helpful or relevant, or they decide to avoid the law when dealing with problems in their lives. Gallagher (2006, 2017), for example, analyzed the limited impact of China's state-led "rule of law" project by examining the legal consciousness of laborers, who resorted to strikes and violence when they realized that labor law and access to state justice conformed to existing market inequalities. Similarly, Albiston (2010) found, on the one hand, that by redefining the social meaning of family and medical leave, a new civil rights statute reshaped the worldviews of workers so that they came to perceive their employers' refusal to grant time off as a legal wrong. On the other hand, workplace rules and norms, management control over time, and cultural assumptions about disabilities reduced the likelihood that the workers would decide to respond to the wrong by filing formal claims. Likewise, Marshall (2005) found that office grievance procedures limited the likelihood that employees would turn to the law to fight against sexual harassment.

Other scholars examine how identity and social position shape the worldviews of their research subjects, influence their perceptions of issues, and consequently determine whether they decide to mobilize their rights in response. For example, Nielsen (2000) shows that men, women, and ethnic minorities differ in their propensity to demand legal protection from offensive public speech. Boittin (2013) explores Chinese sex workers' diverse ways of dealing with abuse and uses legal consciousness analysis to explain why most of them decided not to use the law. Abrego (2011) finds that the age at which undocumented immigrants arrived in the United States and were socialized at work and school affected their identities, leading to differences in their readiness to mobilize the law to solve their problems.

In the Mobilization school, law typically looms as a powerful presence - as in studies by the Hegemony school — but human agency receives more attention and is generally portrayed as less 
constrained by law. The researchers' central concern is not to document law's dominance but to explore the circumstances under which people deploy the law to protect their interests, and thus to better understand law's potential contribution to positive change. Hernández (2010) observes that it is possible for disadvantaged individuals - low-incomes mothers, in her case - to gain legal knowledge, transform their self-identities, perceive themselves as legally entitled, and mobilize the law, rather than cynically shun or dismiss it. In Hull's (2003) study asking whether same-sex couples desire legal recognition for their relationships, her interviewees enact legality in the absence of official law. Hull argues that these findings challenge the idea that marginalized social actors tend to possess resistant legal consciousness and evade law in their everyday lives. Instead, by adopting marriage-related terminology and performing public commitment rituals, same-sex couples embrace law's power to change cultural discourse and meanings - a claim that resonates with later studies on the legal consciousness of gays and lesbians after legally recognized same-sex marriage in the United States became widely available (see, e.g., Richman 2014).

For Mobilization researchers who study legal consciousness to explain the thoughts and actions of those who fight for social change, the primary aim is to examine at close range how human agency interacts with rights to facilitate, hamper, or otherwise influence their efforts. To put it in our definitional terms, they ask whether and how people draw from rights discourse in their perceptions and decisions - to help them make sense of troublesome events or decide on responses to them. McCann (1994), an early representative of this line of research, asked union and feminist activists how they used rights' symbolic and strategic power and mobilized working women to fight for equal pay, even when the courts failed to endorse their formal legal claims. In studies of legal consciousness in the disability rights movement, Vanhala (2011) and Heyer (2015) highlight the various ways in which activists reinterpret rights to expand and enrich the scope of equality protected by state law. Chua $(2015, \underline{2019})$ analyzes how Burmese LGBT (lesbian, gay, bisexual, and transgender) activists creatively infuse international human rights with local understandings about karma, social roles, and responsibility to make human rights meaningful to fellow Burmese and appeal to them to join the movement.

Although their research subjects do not necessarily favor legal strategies or claiming for rights, Mobilization school researchers nevertheless focus on actors' perceptions and decisions about the relevance of rights as solutions to their problems. These researchers use legal 
consciousness analysis to reveal the limits and potential of rights for collective action and social change (see, e.g., Aviram 2008; Chua 2012, 2014; Levitsky 2008, 2014). ${ }^{4}$ Legal consciousness analysis enables them to explain how rights can influence the course of social change even in the absence of explicit claims.

\section{TURBULENCE: THE DEATH AND CONTINUING LIFE OF LEGAL CONSCIOUSNESS RESEARCH}

The report of my death was an exaggeration.

-Mark Twain ${ }^{5}$

By the early 2000s, the field of legal consciousness research experienced turbulence. On the one hand, a few scholars began to question the paradigm itself, suggesting that it might have exhausted its potential and that researchers should move on. On the other hand, legal consciousness scholarship continued to grow, indicating that it had not hit a dead end. Scholars from all three schools, particularly those who focused on understudied populations in a variety of social settings, increasingly found the research paradigm of legal consciousness to be valuable.

The period of self-questioning was punctuated by an essay Susan Silbey published in this journal in 2005. Silbey (2005, p. 358) urged researchers to redirect legal consciousness studies "to recapture the critical sociological project of explaining the durability and ideological power of law." She expressed concern that the field had lost its "critical edge and theoretical utility" (p. 324), "leaving us with studies of individual psychology and its accommodations to predefined policy goals" (p. 359). The very title of her critique, "After Legal Consciousness," suggested that the moment for this type of research may have passed.

Silbey's carefully argued critique is grounded primarily in the Hegemony school. Legal consciousness research, she contends, is meant "to address issues of legal hegemony, particularly how the law sustains its institutional power despite a persistent gap between the law on the books and the law in action" (p. 323). Specifically, this type of research aims to reveal why people "acquiesce" to a legal system that disadvantages and disempowers them (p. 323). Documenting

\footnotetext{
${ }^{4}$ Neither Levitsky $(2008,2014)$ nor Chua $(2012, \underline{2014})$ used the term legal consciousness explicitly to describe their work.

${ }^{5}$ http://www.thisdayinquotes.com/2010/06/reports-of-my-death-are-greatly.html.
} 
individual cases of subjectivity, in her view, has value only to the extent that researchers use them to expose the less accessible, hegemonic forces of cultural production, which infuse everyday life with ideas, values, and images that constrain action and reproduce inequality.

Because legal consciousness research did not atrophy but flourished in the years following publication of Silbey's essay, however, her criticisms may have seemed less salient to researchers in the Identity or Mobilization schools. Two years before the publication of Silbey's essay, Marshall \& Barclay (2003) offered a more sanguine and rather different survey, contending that legal consciousness studies remain useful for understanding how individual subjectivity mobilizes legal norms and institutions to mitigate injustice and produce greater social equality. While sharing Silbey's appreciation for law's constitutive effects, they argued that analysis of legal hegemony is not the sole or even the primary purpose of legal consciousness research. Rather, they endorsed a focus on the agency of individual subjects, the "zone of volition in which individuals make decisions about how law will shape their behavior" (p. 623).

In a more recent response to the Silbey critique, ${ }^{6}$ Hull (2016) points out that scholars have expanded legal consciousness as a research paradigm to marginalized groups to illuminate the important and often positive effects of legal rights as well as the creativity and agency of "ordinary" people. Hull focuses on LGBT-related studies, but her discussion of agency and the strategic use of law among marginalized groups typifies recent legal consciousness research among scholars who have turned their attention to such groups as undocumented immigrants (Abrego 2011, 2018), sexual minorities (Connolly 2002, Harding 2011, Hull 2003, Richman 2014), racial minorities (Hirsh \& Lyons 2010, Morrill et al. 2010), aboriginal populations (Jacobs 2010, McMillan 2011), women (Boittin 2013, Liu 2018, Marshall 2005), workers (Gallagher 2006, He et al. 2013, Hoffmann 2003, Nguyen 2018, Smith 2005), prisoners (Calavita \& Jenness 2014), peasants (Hudson 2001), and the poor (Hernández 2010, Huang et al. 2014).

In fact, legal consciousness studies now explore a broad range of social scientific questions connected to several different research concerns and theories associated with a variety of academic disciplines. A survey of all published books, articles, and chapters with the term legal

\footnotetext{
${ }^{6}$ See also Hertogh (2018), presenting what he views as a European counterpoint to Ewick \& Silbey's analysis.
} 
consciousness in their titles during the past 35 years (Figure 1) suggests that the research paradigm underwent dramatic growth during and after the period of turbulence in the early 2000s. Rather than exposing a conceptual flaw in their understanding of the concept of legal consciousness, the diversity of approaches in these publications illustrates an important strength of sociolegal studies as a field in which scholars share a commitment to examining the place of law in social life but have varied intellectual motivations.

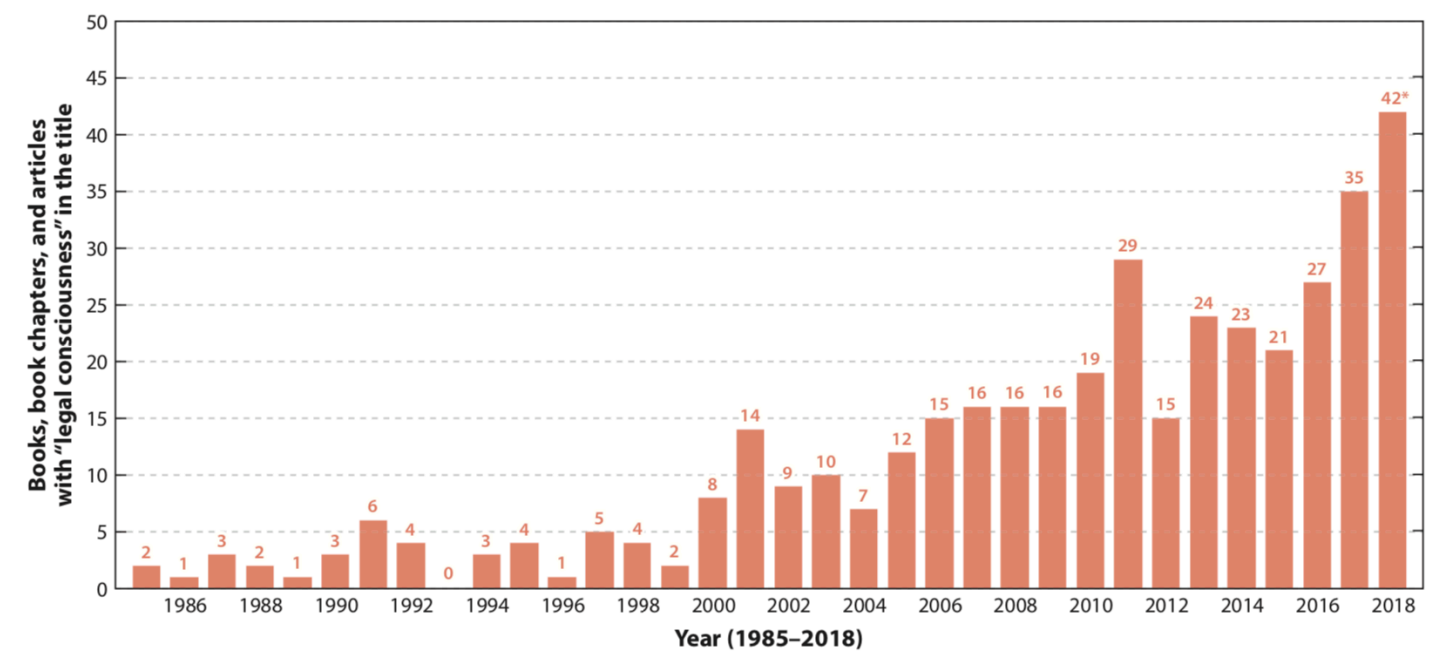

Figure 1

Legal consciousness in titles of scholarly publications. This figure was generated by searching Google Scholar and WorldCat for all scholarly books, articles, and book chapters published worldwide containing the expression "legal consciousness" in the title. Only English-language publications were considered, and where the subject matter was ambiguous from the title, each was read to ensure the accuracy of our classification. Asterisk represents partial count as of March 2019.

The argument against a legal consciousness approach based only on the Hegemony school draws support from the expansion of research conducted outside North America. Insisting on a single theoretical orientation would be unrealistic, perhaps even harmful, for this transnational dialogue. As Liu (2015, p. 6) suggests, sociolegal scholarship's preoccupation with "power/inequality" — which aligns with the motivations of the Hegemony school—is, "to a large extent, a historical product of the progressive intellectual movements in the United States." Although this focus remains important for much of the American sociolegal research agenda, Liu 
contends, the revelation of law's hegemony does not necessarily provide the most enlightening or even relevant analytical tools in other societies. Of course, some legal consciousness studies outside the United States do expose legal hegemony and its manifestations in neoliberal policies (see, e.g., Santos 1995, Santos \& Rodríguez-Garavito 2005), or examine subaltern resistance and the use of subversive tactics to contest official law (see, e.g., Harding 2011, Ho \& Chua 2016, Smith 2005). Other non-American studies, however, are motivated by interests and issues more pertinent to the Identity or Mobilization perspectives. Some examine how individuals, groups, or societies organize themselves or manifest a sense of self (Hertogh \& Kurkchiyan 2016, Kurkchiyan 2011, Michelson 2008, Somanawat 2018, Tungnirun 2018, Khorakiwala 2018). Still others explore the ways in which people interpret the law or use legal solutions to address injustice and solve their grievances (Engel \& Engel 2010, He et al. 2013, Hendley 2011, Hertogh 2009, Huang et al. 2014, Kubal 2015, Liu 2018, Moustafa 2013, Nguyen 2018).

In short, the proliferation of legal consciousness research in the United States and in a growing number of other societies demonstrates that the field has reached not a dead end but a major intersection. Critiques of the field in the early 2000s did promote essential self-reflection that clarified differing research goals under the legal consciousness banner. Meanwhile, scholars from diverse theoretical perspectives, disciplinary backgrounds, and methodological traditions increasingly found legal consciousness to be a valuable research paradigm. They applied its basic concepts and methods to social and cultural contexts and areas of law previously understudied by sociolegal scholars, injecting new energy and insights into the field.

\section{LOOKING AHEAD: RELATIONAL LEGAL CONSCIOUSNESS}

One of the most promising aspects of the growth of legal consciousness research is a trend toward what we call relational legal consciousness. In this section, we discuss the expansion of relational perspectives and the potential for future legal consciousness research that draws more extensively on a relational model. We suggest that the relational turn in legal consciousness research has implications for all three of the components we have emphasized throughout this article-worldview, perspective, and decision.

\section{The Emergence of Relational Legal Consciousness}

Of course, no legal consciousness researcher has ever asserted that individual consciousness 
arises in a social vacuum. To varying degrees, all sociolegal scholars appreciate that humans are social creatures, whose thoughts and actions inevitably reflect their interactions with other individuals, groups, and institutions. In a sense, then, all legal consciousness research is and always has been relational. The recent growth of relational perspectives has been a matter of degree rather than kind. Variations in contemporary legal consciousness research should therefore be imagined on a continuum ranging from highly individualistic and autonomous conceptualizations of thought and action on one end to highly interactive and co-constitutive conceptualizations on the other (compare Crossley 2011, von Benda-Beckmann 2018).

Although concepts of the self as essentially atomistic and autonomous are typically associated with Enlightenment theory of the eighteenth century, the relational perspective on individual consciousness is also apparent in the writings of theorists reaching back at least as far as the nineteenth century if not beyond. For example, the early writings of Marx (1975, pp. 32829) suggested that both worldview and perception in working-class consciousness were relational in nature, emerging from workers' positions vis-à-vis capitalists ( $\underline{\text { Held 2009, }} \underline{\text { Roelvink }}$ 2013, Wartenberg 1982). Near the end of the nineteenth century, Durkheim [1964 (1893)] proposed a relational form of worldview in his concept of a "conscience collective," referring to a set of shared moral beliefs that regulate the thoughts and actions of the members of a society. At about the same time, another theorist, James [1952 (1891), p. 189, emphasis in original], suggested that perception and decision are shaped by one's social relationships - consciousness is fundamentally relational, and in fact, each individual has "as many social selves as there are individuals who recognize him and carry an image of him in their mind." In sum, ideas associated with the Enlightenment notwithstanding, theories of consciousness have always featured competing viewpoints ranging from the individualistic to the relational.

In the late twentieth century, the relational perspective attracted growing attention among Western scholars across the disciplines. Psychologist Gergen (2009, p. 397), for example, emphasizes that individuals do not create meaning one-by-one but construct it by "coordinated action" as relational beings through their communication and interaction with one another. Sociologist Emirbayer (1997, p. 287), in his "Manifesto for a Relational Sociology," rejects the bounded condition of the "person" and instead portrays individuals as "inseparable from the transactional contexts within which they are embedded." Relational theory also featured prominently in the work of some feminist legal scholars. Fineman $(\underline{2008}, \underline{2018})$, for example, 
suggests that all humans are interdependent, "vulnerable," and essentially interconnected; and Nedelsky (2011, p. 19) argues that human subjects of law and government are not freestanding individuals but are "constituted by networks of relationships of which they are a part" (also see Harding 2017).

Furthermore, a more relational approach to legal consciousness has been evident in recent sociolegal research conducted in Asia, Africa, and other settings outside Europe and North America, where the influence of Enlightenment philosophy was uneven and popular understandings of atomistic individualism had shallow roots, if they existed at all. In those settings, legal consciousness researchers have discovered that worldviews, perceptions, and decisions develop relationally, and it is often impossible to disentangle the consciousness of any one person from those of her family members, fellow villagers, or other intimate associates. As Morreira (2016, p. 129) concluded in her study of human rights in Zimbabwe, "One is not a person without the intricate connections one holds to other people" [see also Tanabe 2002, p. 48 and Fei 1992 (1947) as discussed in $\underline{\mathrm{Ng} \& \mathrm{He} 2017]}$. If the self is essentially relational, it follows that an overly individualistic framework will fail to capture the essence of her legal consciousness.

The concept of relational legal consciousness that emerges from these studies in non-Western societies should not, however, be romanticized. To the extent that individual personhood is subsumed within other social relationships, there is a possibility that these relationships are unequal and maintain existing social hierarchies. Certain forms of relational consciousness may normalize the plight of an abused spouse or an exploited laborer (McCann 2017, citing Merry 2003). Nevertheless, some legal consciousness researchers have found that people may effectively mobilize the law because of their relational bonds, not despite them. For example, legal activism among queer Burmese took root after they were invited to join the nascent LGBT rights movement by people whom they knew or trusted, and many of them stayed on because of relationships they subsequently formed with fellow activists (Chua 2019). Likewise, Feldman (2000) suggests that, although members of Japanese society are generally reluctant to assert their rights as individuals, they may be willing to mobilize rights collectively, if enough people band together relationally as a group with similar concerns.

\section{The Relational Legal Consciousness Continuum}

Earlier, we suggested that relational perspectives in the existing literature on legal consciousness 
could be arranged along a continuum from the most individualistic conceptions to the most relational. At one end of the continuum are legal consciousness studies that view the self as essentially autonomous and independent, not entirely divorced from social relationships yet functioning primarily on its own in terms of the worldview-perception-decision making components of thought and action that we have discussed above. Studies in this region of the continuum regard the individual mind as the locus of legal consciousness and assume that researchers should adopt one-by-one or person-by-person methodologies rather than attempting to study the co-constitutive genesis of consciousness in the interactions of two or more minds. To the extent that these researchers consider the influence of other persons or social factors, they regard them as independent variables in relation to the dependent variable of individual worldviews, perceptions, and decisions.

Many studies from the Mobilization school are located in this individualistic region of the continuum, as they analyze how each of their research subjects decides to invoke or avoid law. Often enough, these researchers do consider the influence of interpersonal relationships, but they tend to view such relationships as external to - yet impinging on - the individual's legal consciousness. For example, Morgan (1999) examines how familial ties affect women's decisions to sue for sexual harassment; Merry (2003) shows that the influence of social workers, lawyers, and activists can affect perceptions and decisions to invoke legal resources by women experiencing domestic violence; and Gallagher (2006) and McCann (1994) show that similar interactions with professionals can increase the propensity of Chinese and American workers, respectively, to mobilize their rights.

For researchers affiliated with the Hegemony school, relational concerns are largely implicit in their work, and many can be placed in this individualistic region of the continuum as well. Their studies assume that law's controls and constraints as well as its disempowering ideologies are experienced and reproduced person by person through relationships with external othersgovernment officials and institutions, police, lawyers, judges, and bureaucrats, as well as people and groups to whom individuals may have ties (see, e.g., Ewick \& Silbey 1992, Gilliom 2001). Through the use of case studies, other Hegemony scholars scrutinize how gender, race, ethnicity, and other potentially subordinating attributes influence individuals' relationships, and thus their worldviews, perceptions, and decisions (see, e.g., Nielsen 2000). Yet the tendency, particularly in the earlier legal consciousness studies, was to operationalize these factors as external 
influences on individual thoughts and actions.

Among researchers who analyze legal consciousness individualistically, some highlight power-laden relationships to show how hierarchies and inequalities constrain and control individuals' interactions with other people, groups, and institutions. For instance, $\underline{\operatorname{Li}(2016)}$ considers how the decisions of rural Chinese lawyers to mobilize the law on behalf of their clients are affected by the lawyers' connections with clients, adversaries, and surrounding communities. What Li terms the "relational embeddedness" of these lawyers sheds light on the systemic subordination of rural Chinese, such as indigent elders, divorced women, and villagers, who are in weaker social positions outside the small circle of local elites. Similarly, Liu \& Halliday (2017, p. xii) study politically liberal lawyers in China and conclude that they may be unable to mobilize for social change because they "are not simply individual lawyers floating like professional flotsam on a sea of social and political turbulence" but are constrained by their institutional or personal ties with state agencies or officials. Both of these studies view external hierarchies and unequal power relationships as powerful influences on the individual legal consciousness of legal professionals in China.

Moving toward the middle region of the individualistic/relational continuum, we find legal consciousness studies that retain the individual as the appropriate object of study but treat other individuals as co-creators of consciousness rather than mere external variables. Studies in this region of the continuum, moreover, place a greater emphasis on the porosity of boundaries between individual cognition and relationships with others. Identity school studies, such as that by Engel \& Munger (2003), feature individuals' legal consciousness and their relationships as intertwined in mutually constitutive processes. Because the sense of self is "distributed" across a network of significant others, legal consciousness shifts and morphs as people engage in these important relationships and, in so doing, manifest different aspects of their identities (Engel \& Munger 2003, citing Bruner 1990). Thus, exploring why tort victims do not mobilize the law and sue their injurers, Engel (2016, p. 154) explains that humans "make decisions as part of their social network, even when they act without explicit direction...Human identity isn't formed in solitude. We are our relationships." Similarly, in Merry's (2003) study of abused women in Hilo, Hawaii, the emergence of a more law-oriented form of consciousness came as the women shifted their subjectivities from relationships to kin, family, and work to relationships with state actors. With these shifts came an increased tendency for the women to view themselves as rights 
subjects.

Studies in this region of the continuum tend to place greater emphasis on group membership as a critically important factor in shaping legal consciousness, not only because group norms are widely shared but because maintaining one's standing in the group is itself a primary motivation. As Nadler (2017, p. 60) observes, "The way in which people interact with law is mediated by group life." In her view,

To talk about how law influences individual behavior in a vacuum, devoid of social context, is to ignore the ways that group identity interacts with law to provide motivations to comply. These include motives to cooperate, to be loyal to the group, to adhere to group norms, and to avoid social exclusion. (Nadler 2017, p. 70 , citations omitted)

Some Identity school studies in the continuum's middle region emphasize that individual legal consciousness is inextricable from the meaning-making activities of a group. Rather than taking the group or community as a given, they show that individuals can actually create community with their legal consciousness as much as the community creates their legal consciousness and sense of self. For example, Tungnirun (2018) finds that foreign corporate lawyers construct two different communities with their divergent understandings of law in Myanmar - one that assimilates with native lawyers and another that carries a sense of legal superiority and sets itself apart. Tungnirun calls these "communities of meaning," making use of a term coined by Engel (1998, referring to Greenhouse 1988 and Yngvesson 1988). In such research, people participating in ongoing relationships produce a legal consciousness that sustains their community and bestows membership on those identified as insiders, who share assumptions about the appropriate use and nonuse of law.

Finally, at the other end of the continuum, is a concept of relationalism that rejects the individual as the unit of analysis and views legal consciousness as a fully collaborative phenomenon. In this perspective, legal consciousness is not formulated person by person but is constituted by their very relationships and exists among and between individual minds rather than within them. This type of legal consciousness can take on as many different forms as there are relationships — among couples, families, groups, associations, communities, and so on. Because individuals have multiple relationships, they participate in — and help to constitutemultiple forms of collective legal consciousness. 
The co-constitutive model of legal consciousness reflects a well-established tradition of social theory. For example, Merleau-Ponty [2012 (1945), p. 370] theorized a form of consciousness arising in its totality from dialogue with another, a "being-shared-by-two" in which "we are, for each other, collaborators in perfect reciprocity: our perspectives slip into each other, we coexist through a single world." Contemporary practice theorists, such as Bourdieu (1977), postulate what Warde (2016, p. 42) calls "integrative practice," which functions at the level of the "supraindividual" and exists on its own terms and "for itself." The life experiences of individuals are associated with collective forms of legal consciousness that transcend the thoughts and actions of any single person. ${ }^{7}$

Although legal consciousness scholars have not fully theorized a purely co-constitutive model, some recent writings seem to venture in this direction. For example, Young (2014) postulates a "second-order legal consciousness" that transcends individualized models and resides outside any single person. She suggests that "a person's beliefs about, and attitude toward, a particular law or set of laws is influenced not only by his own experience, but by his understanding of others' experiences with, and beliefs about, the law" (p. 500; see discussion of Young's analysis in Hull 2016). Abrego (2018), in her discussion of the effects of Deferred Action for Childhood Arrivals (DACA) in the United States, also implies that legal consciousness can exist at a collective level. Although DACA targeted undocumented immigrants as individuals, Abrego (2018, p. 204, emphasis added) finds that its benefits enabled families of DACA recipients to "move away from a family legal consciousness based on infantilizing experiences when they had to rely on favors from others to meet basic family needs, to a legal consciousness of family independence through interdependence on DACA recipients."

Because the co-constitutive region of the relational legal consciousness continuum has not been fully theorized, some critically important questions still await analysis. It is not clear

\footnotetext{
${ }^{7}$ We are grateful to Kwai $\mathrm{Ng}$ and Keebet von Benda-Beckmann for their suggestions about this type of relational legal consciousness.

${ }^{8} \underline{\text { Nadler (2017) }}$ claims that law interacts directly with a group to shape its norms and values, and thus "group identity" influences individuals' thoughts and actions. This raises questions, which are not explicitly addressed in her article, about how group identity develops, how a "group" interacts with law, and how a group-level type of legal consciousness takes shape as a result.
} 
whether all legal consciousness is to be deemed relational or just some types, nor is it obvious how some participants in a relationship adopt features of collective legal consciousness but others do not. The co-constitutive process itself has not been described and documented, nor have the dynamics between individual legal consciousness (if any) and the collective form. Should we now imagine relational legal consciousness to be something like a computer cloud storage shared by multiple users? Do individuals download relevant contents from the cloud as they perceive their experiences and make decisions in response? Do they upload new or modified contents to the cloud?

In the most extreme form of a co-constitutive model, individual subjectivity might fade completely into relationships, and researchers might abandon the individual entirely as the relevant unit of analysis. Instead, they would treat dynamic relations as the proper object of inquiry (Emirbayer 1997, Liang \& Liu 2018) and would therefore view legal consciousness as existing only as part of the relationships among two or more people. If such a view were fully adopted, a significant modification in research methodology would be required. The person-byperson research methods used by legal consciousness scholars from the early 1980s to the present could become irrelevant. Instead, researchers would need to devise new approaches that focus on the observation and analysis of relationships and social interactions to determine how different forms of legal consciousness arise from the dialogic process that produces MerleauPonty's [2012 (1945), p. 370] “being-shared-by-two.” What those methodologies might look like, and how they might be operationalized, is not yet apparent.

\section{CONCLUSION}

From the early 1980s to the present, legal consciousness research has provided sociolegal scholars with new insights into the mutually constitutive relationships among legal practices; the worldviews, perspectives, and decisions of individual actors and groups; and the broader social and cultural contexts in which they live. For Identity, Hegemony, and Mobilization scholars, it has illuminated the connections among law and conceptions of the self; it has revealed the often hidden operations of power, inequality, and oppression; and - at times - it has highlighted the capacity of law to change lives for the better even when it is not directly invoked or used instrumentally. Legal consciousness research is thus a flexible paradigm capable of different kinds of applications in the hands of researchers with different goals and perspectives. 
On the whole, legal consciousness researchers have resisted a singular, monolithic approach. Emerging from a period of questioning and self-criticism at the turn of the twenty-first century, the field has flourished and has remained one of the most active areas of sociolegal research. A new generation of scholars has explored new directions in legal consciousness research, often based on fieldwork in non-American settings as well as in marginalized communities and peoples in the United States, and have contributed to insights across the three schools.

Growth in the field of legal consciousness has been accompanied by an increased attention to its relational and co-constitutive aspects. The trend toward a less individualistic perspective is partly a result of influence from relational theory across the academic disciplines and partly a product of sociolegal research conducted in cultural contexts where Enlightenment philosophies of the self are less firmly rooted. We have suggested that legal consciousness research in all three schools can be arranged along an individualistic-relational continuum, although the more purely relational-or co-constitutive - conceptions of legal consciousness are the most speculative and least developed, at least for now.

We anticipate that future researchers will take on the questions and challenges involved in highly relational approaches of legal consciousness study - in Western as well as in non-Western settings, where individualistic approaches have proved to be particularly ill-suited. Increased attention to relational legal consciousness has the potential to reshape all three schools, leading to formulations of new questions, research designs, and theories about when and how law becomes active. In short, relational legal consciousness represents a promising development for the cultural turn that has enriched sociolegal scholarship for the past several decades and could ensure the continued vitality of legal consciousness as a research paradigm for many years to come.

\section{ACKNOWLEDGMENTS}

We are grateful to Leisy Abrego, Keebet von Benda-Beckmann, Marc Hertogh, Sida Liu, Michael McCann, Frank Munger, Kwai Hang Ng, and Kathryne Young for their feedback and to Neal Johnson, Lu Zhao Boyu, Daryl Yang, and Keyi Yang for their research assistance. We presented earlier drafts of this essay at the 2017 Law \& Society Association and Asian Law \& Society Association annual meetings, where we received valuable comments from audience members. Funding was provided by the National University of Singapore's Ministry of 
Education Tier II Academic Research Fund (R-241-000-168-112).

\section{LITERATURE CITED}

Abrego JL. 2008. Legitimacy, social identity, and the mobilization of law: the effects of Assembly Bill 540 on undocumented students in California. Law Soc. Inq. 33(3):709-34 Abrego JL. 2011. Legal consciousness of undocumented Latinos: fear and stigma as barriers to claims-making for first- and 1.5-generation immigrants. Law Soc. Rev. 45(2):337-70

Abrego JL. 2018. Renewed optimism and spatial mobility: legal consciousness of Latino Deferred Action for Childhood Arrivals recipients and their families in Los Angeles. Ethnicities 18(2):192-207

Albiston RC. 2006. Legal consciousness and workplace rights. In New Civil Rights Research: A Constitutive Approach, ed. B Fleury Steiner, LB Nielsen, pp. 55-75. Burlington VT: Ashgate Albiston RC. 2010. Institutional Inequality and the Mobilization of the Family and Medical Leave Act: Rights on Leave. New York: Cambridge Univ. Press

Aviram H. 2008. Make love, now law: perceptions of the marriage equality struggle among polyamorous activists. J. Bisex. 7(3-4):261-86

von Benda-Beckmann K. 2018. Relational social theories and legal pluralism. Paper presented at the Conference on Citizenship, Legal Pluralism and Governance in the Age of Globalization, Commission on Legal Pluralism, Aug. 22-24, Ottawa, Can.

Boittin ML. 2013. New perspectives from the oldest profession: abuse and the legal consciousness of sex workers in China. Law Soc. Rev. 47(2):245-78

Bourdieu P. 1977. Outline of a Theory of Practice, transl. R Nice. Cambridge, UK: Cambridge Univ. Press (from French)

Bruner J. 1990. Acts of Meaning. Cambridge, MA: Harvard Univ. Press

Calavita K, Jenness V. 2014. Appealing to Justice: Prisoner Grievances, Rights, and Carceral Logic. Berkeley: Univ. Calif. Press

Chua LJ. 2012. Pragmatic resistance, law, and social movements in authoritarian states: the case of gay collective action in Singapore. Law Soc. Rev. 46(4):713-48

Chua LJ. 2014. Mobilizing Gay Singapore: Rights and Resistance in an Authoritarian State. Philadelphia: Temple Univ. Press 
Chua LJ. 2015. The vernacular mobilization of human rights in Myanmar's sexual orientation and gender identity movement. Law Soc. Rev. 49(2):299-332

Chua LJ. 2019. The Politics of Love: LGBT Mobilization and Human Rights as a Way of Life. Palo Alto, CA: Stanford Univ. Press

Connolly C. 2002. The voice of the petitioner: the experiences of gay and lesbian parents in successful second-parent adoption proceedings. Law Soc. Rev. 36(2):325-46

Crossley N. 2011. Towards Relational Sociology. London: Routledge

de Certeau M. 1984. The Practice of Everyday Life. Chicago: Univ. Chicago Press

Durkheim E. 1964 (1893). The Division of Labor in Society, transl. G Simpson. New York: Free Press (from French)

Emirbayer M. 1997. Manifesto for a relational sociology. Am. J. Sociol. 103(2):281-317

Engel DM. 1998. How does law matter in the constitution of legal consciousness? In How Does Law Matter?, ed. BG Garth, A Sarat, pp. 109-44. Evanston, IL: Northwestern Univ. Press Engel DM, Munger FW. 2003. Rights of Inclusion: Law and Identity in the Life Stories of Americans with Disabilities. Chicago: Univ. Chicago Press

Engel DM, Engel JS. 2010. Tort, Custom, and Karma: Globalization and Legal Consciousness in Thailand. Palo Alto, CA: Stanford Univ. Press

Engel DM. 2016. The Myth of the Litigious Society: Why We Don't Sue. Chicago: Univ. Chicago Press

Ewick P, Silbey SS. 1992. Conformity, contestation, and resistance: an account of legal consciousness. N. Engl. Law Rev. 26:731-49

Ewick P, Silbey SS. 1998. The Common Place of Law: Stories from Everyday Life. Chicago: Univ. Chicago Press

Fei X. 1992 (1947). From the Soil: The Foundations of Chinese Society, transl. GG Hamilton, W Zheng. Berkeley: Univ. Calif. Press (from Chinese)

Feldman E. 2000. The Ritual of Rights in Japan: Law, Society, and Health Policy. Cambridge, UK: Cambridge Univ. Press

Fineman MA. 2008. The vulnerable subject: anchoring equality in the human condition. Yale J. Law Fem. 20(1):1-23

Fineman MA. 2018. Injury in the unresponsive state: writing the vulnerable subject into neoliberal legal culture. In Injury and Injustice: The Cultural Politics of Harm and Redress, ed. 
A Bloom, DM Engel, M McCann, pp. 50-75. Cambridge, UK: Cambridge Univ. Press

Foucault M. 1980. Power/Knowledge: Selected Interviews and Other Writings 1972-1977, ed. C

Gordon, transl. C Gordon. New York: Random House (from French)

Fritsvold ED. 2009. Under the law: legal consciousness and radical environmental activism. Law Soc. Inq. 34(4):799-824

Gallagher M. 2006. Mobilizing the law in China: "informed disenchantment" and the development of legal consciousness. Law Soc. Rev. 40(4):783-816

Gallagher M. 2017. Authoritarian Legality in China. Cambridge, UK: Cambridge Univ. Press

Gergen KJ. 2009. Relational Being: Beyond Self and Community. New York: Oxford Univ. Press

Gilliom J. 2001. Overseers of the Poor: Surveillance, Resistance, and the Limits of Privacy. Chicago: Univ. Chicago Press

Goffman E. 1963. Stigma: Notes on the Management of Spoiled Identity. New York: Simon \& Schuster

Greenhouse CJ. 1988. Courting difference: issues of interpretation and comparison in the study of legal ideologies. Law Soc. Rev. 22(4):687-708

Harding R. 2011. Regulating Sexuality: Legal Consciousness in Lesbian and Gay Lives. London: Routledge

Harding R. 2017. Duties to Care: Dementia, Relationality and Law. Cambridge, UK: Cambridge Univ. Press

Hartog H. 1995. Abigail Bailey's coverture: law in a married woman's consciousness. In Law in Everyday Life, ed. A Sarat, T Kearns, pp. 63-108. Ann Arbor: Univ. Mich. Press

He X, Wang L, Yang S. 2013. Above the roof, beneath the law: perceived justice behind disruptive tactics of migrant wage claimants in China. Law Soc. Rev. 47(4):703-38

Held JM. 2009. Marx via Feuerbach: species-being revisited. Ideal. Stud. 39(1-3):137-48

Hendley K. 2011. Resolving problems among neighbors in post-Soviet Russia: uncovering the norms of the pod"ezd. Law Soc. Inq. 36(2):388-418

Hernández D. 2010. Special issue interdisciplinary legal studies: the next generation. Stud. Law Politics Soc. 51:95-121

Hertogh M. 2009. What's in a handshake? Legal equality and legal consciousness in the Netherlands. Soc. Leg. Stud. 18(2):221-39

Hertogh M. 2018. Nobody's Law: Legal Consciousness and Legal Alienation in Everyday Life. 
London: Palgrave Macmillan

Hertogh M, Kurkchiyan M. 2016. "When politics comes into play, law is no longer law": images of collective legal consciousness in the UK, Poland and Bulgaria. Int. J. Law Context 12(4):404-19

Heyer K. 2015. Rights Enabled: The Disability Revolution, from the US, to Germany and Japan, to the United Nations. Ann Arbor: Univ. Mich. Press

Hirsh E, Lyons CJ. 2010. Perceiving discrimination on the job: legal consciousness, workplace context, and the construction of race discrimination. Law Soc. Rev. 44(2):269-98

Ho ELE, Chua LJ. 2016. Law and "race" in the citizenship spaces of Myanmar: spatial strategies and the political subjectivity of the Burmese Chinese. Ethnic Racial Stud. 39(5):896-916

Hoffmann EA. 2003. Legal consciousness and dispute resolution: different disputing behavior at two similar taxicab companies. Law Soc. Rev. 28(3):691-716

Huang KC, Lin CC, Chen KP. 2014. Do rich and poor behave similarly in seeking legal advice? Lessons from Taiwan in comparative perspective. Law Soc. Rev. 48(1):193-223

Hudson HD. 2001. "Even if you cut off our heads": Russian peasant legal consciousness in the first half of the nineteenth century. Can.-Am. Slav. Stud. 35(1):1-17

Hull KE. 2003. The cultural power of law and the cultural enactment of legality: the case of same-sex marriage. Law Soc. Inq. 28:629-57

Hull KE. 2016. Legal consciousness in marginalized groups: the case of LGBT people. Law Soc. Inq. 41(3):551-72

Jacobs LA. 2010. Mapping the legal consciousness of First Nations voters: understanding voting rights mobilization. Pap. 36, Aborig. Policy Res. Consort. Int., Ont., Can.

James W. 1952 (1891). The Principles of Psychology. New York: Henry Holt \& Co.

Khorakiwala R. 2018. Legal consciousness as viewed through the judicial iconography of the Madras High Court. Asian J. Law Soc. 5(1):111-133

Kirkland A. 2008. Think of the hippopotamus: rights consciousness in the fat acceptance movement. Law Soc. Rev. 42(2):397-432

Kostiner I. 2003. Evaluating legality: toward a cultural approach to the study of law and social change. Law Soc. Rev. 37(2):323-68

Kubal A. 2015. Legal consciousness as a form of social remittance? Studying return migrants' everyday practices of legality in Ukraine. Migr. Stud. 3(1):68-88 
Kurkchiyan M. 2011. Perceptions of law and social order: a cross-national comparison of collective legal consciousness. Wis. Int. Law J. 29:366-89

Levitsky S. 2008. "What's rights?": the construction of political claims to American health care entitlements. Law Soc. Rev. 42(3):551-89

Levitsky S. 2014. Caring for Our Own: Why There Is No Political Demand for New American Social Welfare Rights. New York: Oxford Univ. Press

Li K. 2016. Relational embeddedness and socially motivated case screening in the practice of law in rural China. Law Soc. Rev. 50(4):920-52

Liang L, Liu S. 2018. Beyond the manifesto: Mustafa Emirbayer and relational sociology. In The Palgrave Handbook of Relational Sociology, ed. F Dépelteau, pp. 395-411. Basingstoke, UK: Palgrave Macmillan

Liu Q. 2018. Legal consciousness of the leftover woman: law and Qing in Chinese family relations. Asian J. Law Soc. 5:7-27

Liu S. 2015. Law's social forms: a powerless approach to the sociology of law. Law Soc. Inq. 40(1): $1-28$

Liu S, Halliday TC. 2017. Criminal Defense in China: The Politics of Lawyers at Work. Cambridge, UK: Cambridge Univ. Press

Marshall AM. 2005. Confronting Sexual Harassment: The Law and Politics of Everyday Life. Abingdon, UK: Routledge

Marshall AM, Barclay S. 2003. In their own words: how ordinary people construct the legal world. Law Soc. Inq. 28(3):617-28

Marx K. 1975. Early Writings, transl. R Livingstone, G Benton. London: Penguin Books (from German)

McCann MW. 1994. Rights at Work: Pay Equity Reform and the Politics of Legal Mobilization. Chicago: Chicago Univ. Press

McCann M. 2017. Listening for the songs of others. In Insiders, Outsiders, Injuries, and Law: Revisiting “The Oven Bird's Song,” ed. MN Trautner, pp. 139-60. Cambridge, UK: Cambridge Univ. Press

McMillan LJ. 2011. Colonial traditions, co-optations, and Mi'kmaq legal consciousness. Law Soc. Inq. 36(1):171-200

Merleau-Ponty M. 2012 (1945). Phenomenology of Perception, transl. DA Landes. New York: 
Routledge (from French)

Merry S. 1990. Getting Justice and Getting Even: Legal Consciousness among Working-Class Americans. Chicago: Univ. Chicago Press

Merry SE. 2003. Rights talk and the experience of law: implementing women's human rights to protection from violence. Hum. Rights Q. 25(2):343-81

Michelson E. 2008. Dear Lawyer Bao: everyday problems, legal advice, and state power in China. Soc. Probl. 55(1):43-71

Minow M. 1990. Making All the Difference: Inclusion, Exclusion, and American Law. Ithaca, NY: Cornell Univ. Press

Morgan PA. 1999. Risking relationships: understanding the litigation choices of sexually harassed women. Law Soc. Rev. 33:67-91

Morreira S. 2016. Rights After Wrongs: Local Knowledge and Human Rights in Zimbabwe. Palo Alto, CA: Stanford University Press

Morrill C, Edelman LB, Tyson K, Arum R. 2010. Legal mobilization in schools: the paradox of rights and race among youth. Law Soc. Rev. 44(3-4):651-93

Moustafa T. 2013. Islamic law, women's rights, and popular legal consciousness in Malaysia. Law Soc. Inq. 38(1):168-88

Munger F. 1998. Mapping law and society. In Crossing Boundaries: Traditions and Transformations in Law \& Society Research, ed. M Constable, DM Engel, V Hans, S Lawrence. Evanston, IL: Northwestern Univ. Press

Nadler J. 2017. Expressive law, social norms, and social groups. Law Soc. Inq. 42(1):60-75

Nedelsky J. 2011. Law's Relations: A Relational Theory of Self, Autonomy, and Law. New York: Oxford Univ. Press

Ng KH, He X. 2017. Embedded Courts: Judicial Decision-Making in China. Cambridge, UK: Cambridge Univ. Press

Nguyen TP. 2018. Labor law and (in)justice in workers' letters in Vietnam. Asian J. Law Soc. 5:29-47

Nielsen LB. 2000. Situating legal consciousness: experiences and attitudes of ordinary citizens about law and street harassment. Law Soc. Rev. 34:1055-89

Richman KD. 2014. License to Wed: What Legal Marriage Means to Same-Sex Couples. New York/London: NYU Press 
Roelvink G. 2013. Rethinking species_-being in the anthropocene. Rethink. Marxism 25(1):5269

Santos B. 1995. Toward a New Common Sense: Law, Science and Politics in the Paradigmatic Transition. Abingdon, UK: Routledge

Santos B, Rodríguez-Garavito C, eds. 2005. Law and Globalization from Below: Towards a Cosmopolitan Legality. Cambridge, UK: Cambridge Univ. Press

Sarat A. 1990. "The law is all over": power, resistance and the legal consciousness of the welfare poor. Yale J. Law Humanit. 2:343-79

Seron C, Silbey S. 2004. Profession, science, and culture: an emergent canon of law and society research. In The Blackwell Companion to Law and Society, ed. A Sarat, pp. 30-59. Malden, MA: Blackwell Publ.

Silbey SS. 2005. After legal consciousness. Annu. Rev. Law Soc. Sci. 1:323-68

Smith AA. 2005. Legal consciousness and resistance in Caribbean seasonal agricultural workers. Can. J. Law Soc. 20(2):95-122

Somanawat K. 2018. Constructing the identity of the Thai Judge: virtue, status, and power. Asian J. Law Soc. 5(1):91-110

Tanabe S. 2002. The person in transformation: body, mind and cultural appropriation. In Cultural Crisis and Social Memory: Modernity and Identity in Thailand and Laos, ed. S Tanabe, CF Keyes, pp. 43-67. Honolulu: Univ. Hawai'i Press

Tungnirun A. 2018. Practicing on the moon: globalization and legal consciousness of foreign corporate lawyers in Myanmar. Asian J. Law Soc. 5(1):49-67

Vanhala L. 2011. Making Rights a Reality? Disability Rights Activists and Legal Mobilization. New York: Cambridge Univ. Press

Warde A. 2016. The Practice of Eating. Cambridge, UK: Polity

Wartenberg TE. 1982. "Species-being” and "human nature" in Marx. Hum. Stud. 5(2):77-95

Wilson JC. 2011. Sustaining the state: legal consciousness and the construction of legality in competing abortion activists' narratives. Law Soc. Inq. 36(2):455-83

Yngvesson B. 1988. Making law at the doorway: the clerk, the court, and the construction of community in a New England town. Law Soc. Rev. 22(3):409-48

Yngvesson B. 1993. Virtuous Citizens, Disruptive Subjects: Order and Complaint in a New England Court. New York: Routledge 
Young KM. 2014. Everyone knows the game: legal consciousness in the Hawaiian cockfight. Law Soc. Rev. 48(3):499-530 